\title{
A Few Things that Every New York Pupil in Grammar Grades Should Know
}

\section{Amos W. Farnham}

To cite this article: Amos W. Farnham (1912) A Few Things that Every New York Pupil in Grammar Grades Should Know, Journal of Geography, 10:7, 237-240, DOI: 10.1080/00221341208985698

To link to this article: http://dx.doi.org/10.1080/00221341208985698

曲 Published online: 20 May 2008.

Submit your article to this journal $\lceil\pi$

Џ Article views: 3

Q View related articles $\square$ 
too soon. In the early autum of 1911 the apparent storage supply in the Croton system was estimated to be sufficient for only about a month. Strenuous measures were taken to cut down waste and to guard all supplies of the city. The Summer season had been abnormally dry and a water famine was a certainty unless normal precipitation should relieve the Iong drought. Heavy rains came in October, storage reservoirs are now replenished, and the danger is probably permanently averted, for, unless the Summer season of 1912 shall prove to be still more abnormally dry the Catskill supply will reach the city before the next return of such conditions. When the system is completed New York City will have doubled its water supply and will be able to use daily more than 1,000,000,000 gallons of most excellent water.

\title{
A FEW THINGS THAT EVERY NEW YORK PUPIL IN GRAM- MAR GRADES SHOULD KNOW
}

\author{
By AMOS W. FARNHAM, \\ Oswego State Normal and Training School
}

I. Regaraing latitude and longitude: That the morthern boundary of New York extending from the St. Lawrence River due east is the parallel of forty-five degress north latitude, which means that this boundary is due north from the equator a distance of forty-five degress of latitude. Since the north pole is ninety degrees distant from the equator then every point in the forty-fifth parallel of north latitude is midway in latitude and nearly midway in distance between the equator and the north pole. The parallel of forty-five degrees north latitude is also the northern boundary of Vermont, Wyoming, and Yellowstone National Park. The southern boundary of New York that extends east-west is the parallel of forty-two degrees north latitude. This parallel is also the northern boundary of California, of Nevada, and of a part of Utah.

The meridian of seventy-four degress and three seconds west longitude passes through the City. Hall of Greater New York; the meridian of seventy-three degrees and forty-five minutes through Albany; and the meridian of seventy-eight degress and fifty-five seconds through Buffalo.

II. Standard Time: Sun time for all the people of New York even would cause much trouble and more confusion. Hence our country with other civilized countries has adopted a system of standard time. People have. considered all places in any standard time section as having the same longitude from Greenwich; fifteen degrees, thirty degrees, forty-five degrees, and so on, so that the difference in time of Greenwich and any given place shall be in whole hours, and the difference in time of any two given places shall be in whole hours. The meridians which govern the standard time sections of the United States are the seventy-fifth, the ninetieth, the 
one hundred fifth, and the one hundred twentieth. New York has the time of the seventy-fifth meridian, hence all places from New York City to Buffalo have the same clock time, which is five hours earlier than Greenwich time.

III. Light and Heat: Nearly all our light and heat come from the sun. The angle formed by the sun's ray and an exposed surface is called the angle of insolation. The more nearly the angle approaches a right angle the greater the degree of insolation. It follows then that anywhere outside the tropics, hence anywhere in New York State, the southern slopes receive more heat than slopes of any other direction or surfaces lying in a horizontal plane. Not only the angle of insolation but the duration of insolation (length of day) determines the degree of insolation. The angle of insolation at Malone is farther from a right angle than it is in New York City. But Malone has a longer day. Each city loses in one respect and gains in another. These differences would be more apparent if the places considered were farther apart, as Montreal and New York City.

Temperature is not heat; it is the degree of heat, and is measured by the thermometer. Places having the same degree of heat may be connected by lines called isotherms. Hence the temperature of any region may be mapped.

IV. Rainfall: Rainfall is governed by certain laws.

(1) Rainfall decreases as latitude increases.

(2) Rainfall increases as altitude increases up to a certain height and then decreases. The "certain height" decreases as latitude increases.

(3) Rainfall is greater on the windward side of mountains than on the leeward side.

(4) Rainfall is determined by (a) nearness to large bodies of water and the temperature of their surface waters; $(b)$ the direction of the prevailing winds, and (c) the relief (elevation and surface undulations) of the region. The warmer the atmosphere the greater its capacity for water vapor.

A wind moving southward is increasing in temperature, hence increasing in capacity for water-vapor and is therefore a moisture-gathering wind. A wind moving northward is decreasing in temperature, hence decreasing in capacity for water-vapor and is therefore a moisture-giving wind.

A wind to cross a mountain range must rise; as it rises it expands (because of diminished air pressure); as it expands it cools; as it cools it gives its temperature to the water vapor which it carries; as the water vapor cools it condenses and falls as rain (or snow) on the windward side of the mountain range. As the wind reaches the crest of the range it descends (due to the pull of gravity); as it descends it condenses; as it condenses its temperature increases, hence its capacity for water-vapor increases and it becomes a moisture-gathering wind. 
V. Topography: New York has every kind of geographic form except desert; and even deserts of limited areas are represented by the sand dunes of the eastern shores of Lake Ontario, of Long Island, and Central New York. New York is rich in mountains, plateaus, valleys, plains, islands, lakes, streams, water-falls, canyons, and caverns. The highlands culminate in Mt. Marcy and Whiteface, peaks of the Adirondacks, whose heights are respectively 5,345 feet and $4,8 \% 0$ feet above sea level. The valleys, especially the Hudson and the Mohawk, have furnished material for song and story. The Thousand Islands and Niagara Falls are knowu throughout the civilized world, for their beauty and grandeur. The canyon (chasm) of the Au Sable is one of the most remarkable of the kind east of the Rocky Mountains. The quiet beauty of the Finger Lake Region attracts thousands of vacationists every summer. The continental glacier that moved over nearly all the area included within the boundary of New York added to the picturesqueness of the scenery. The local hills are glacial deposits, either drumlins, kames, eskers, or moraines. Nearly all the lakes and water-falls of the state and the soil as well had their origin in the glacier.

The relief is shown on maps by means of contours. A contour is a line that represents the location of places of equal altitude.

VI. Industries: New York takes high rank in every one of the seven great industries. She leads the states in the production of hay, potatoes, hops, milch cows, milk, and cheese. Greater New York consumes 1,500,000 quarts of milk and cream daily. Eighty-seven per cent of this supply comes from the state of New York. New York is second only to Iowa in the production of dairy products. The first cheese factory was built in 1851 in Oneida County and the first creamery in 1861 in Orange county.

New York leads the states in the development of electrical energy by water power. New York city makes one-tenth of all the manufactured products of the United States. No other American city approaches New York in the printing and publishing industry. The various interests centering in New York make it the financial and banking center of the entire country.

New York is the leading commercial center of the Union. "From Tappan Sea to the mouth of New York Bay probably a greater number of ressels ply than can be found on any other river in the world." New York harbor is the finest harbor of the American Continent.

VII. Schools: The frrst New York school-master was Adam Roelandson. His school was a private school which he opened in 1633. "Adam" came from Holland in company with Wouter Van Twiller, the second governor of the New Netherland colony. We are told that the schoolmaster "soon made himself a thorn in the side of about everybody else." 
Soon all his pupils left him and he was compelled to look elsewhere for his living. So he became a "washerman."

Two private schools were opened in 16t5. Both schools prospered. The price of tuition for one year was "two dried beaver skins."

Through the efforts of Governor Peter Stuyyesant the first public school in America was opened in a building on Pearl Street, April, 1652. "A very able and highly educated gentleman, Doctor La Montague, was the first teacher, and he gave his services without pay. One of his successors received a salary of fourteen and one-half dollars a month, with an extra allowance of fifty dollars a year for his board."-From The Mahing of the Empire State.

In $17 \%$ was founded King's College which in less than thirty years lecame Columbia College, now Columbia Eniversity. In 1795, for the first time, the legislature gave a snall sum of money towards the support of schools. In 1813 the state determined to take charge of the schools, and to aid in carrying out the work a State Superintendent of Public Instruction was appointed. Governor DeWitt Clinton, the man who helped New York State to the Erie Canal, never lost an opportunity to speak in the educational interests of the boys and girls. He appealed "for free schools, for better schools, for well-educated teachers, and well-trained, broad-minded boys and girls." Free schools were not fully realized until 1867 .

"We are apt to look upon war as a great horror, as indeed it is. But war is less horrible than ignorance; lack of patriotism and wide-spread dishonesty are vices that are even more deadly to a nation than war. If people become forgetful of the debt they owe their country-if they forget that self-government requires intelligent thought, absolute honesty, and the sacrifice of self, they need to be promptly shaken into a sense of their duty. And if a war is the only thing to stimulate them to duty, the quicker it comes the better. Indeed, there is one warfare that should always keep the people of a nation in arms-the warfare against ignorance, dishonesty, and vice. And if the State of New York is to remain the Empire State in years to come, it will be, not because of her great wealth and wonderful resources, but because of the industry and integrity of the men and women who are now boys and girls in her schools."-Jacques Wardlaw Redway.

VIII. The Empire State: New York is called the Empire State because she leads the states of the Union in population, manufactures, commerce, and wealth. That she may train her youth to become efficient citizens she spends about thirty-five million dollars annually on her public schools. 